\title{
MICROBIOLOGICAL AND PHYSICO-CHEMICAL CHARACTERIZATION OF THE RODRIGUAN CHINESE SAUSAGE
}

\author{
CARACTÉRISTIQUeS MICROBIOlOGIQUeS ET PHYSICO-CHIMIQUeS \\ DE LA SAUCISSE CHINOISE DE RODRIGUES
}

\section{CARACTERÍSTICAS MICROBIOLÓGICAS Y FÍSICO-QUÍMICAS DE LA SALCHICHA CHINA DE RODRÍGUES}

\author{
V.K. Ah Kang1 K. Boodhoo ${ }^{1 *}$ S.J. Santchurn ${ }^{1}$
}

\author{
Keywords: Pork - Sausage - Food processing - Food quality - \\ Microbiology - Mauritius. \\ Mots-clés: Viande porcine - Saucisse - Transformation \\ des produits alimentaires - Qualité des aliments - \\ Microbiologie - Maurice. \\ Palabras clave: Carne de cerdo - Salchicha - \\ Procesamiento de alimentos - Calidad de los alimentos - \\ Microbiología - Mauricio.
}

$\mathrm{R}_{\mathrm{a}}^{\mathrm{a}}$ odrigues Island is a dependency of the Republic of Mauritius and is located at about $653 \mathrm{~km}$ northeast of it. Pig fattening is an important livestock activity in Rodrigues and pork is the most widely consumed meat (1). It is reported that Rodriguan pork has special sensorial attributes, firstly because pigs are fed with traditional starchy crops such as cassava, banana and sweet potato, and kitchen wastes, and secondly because of the rearing method which is mainly an outdoor system. In a previous study (2), the range of processed products made from pork and their

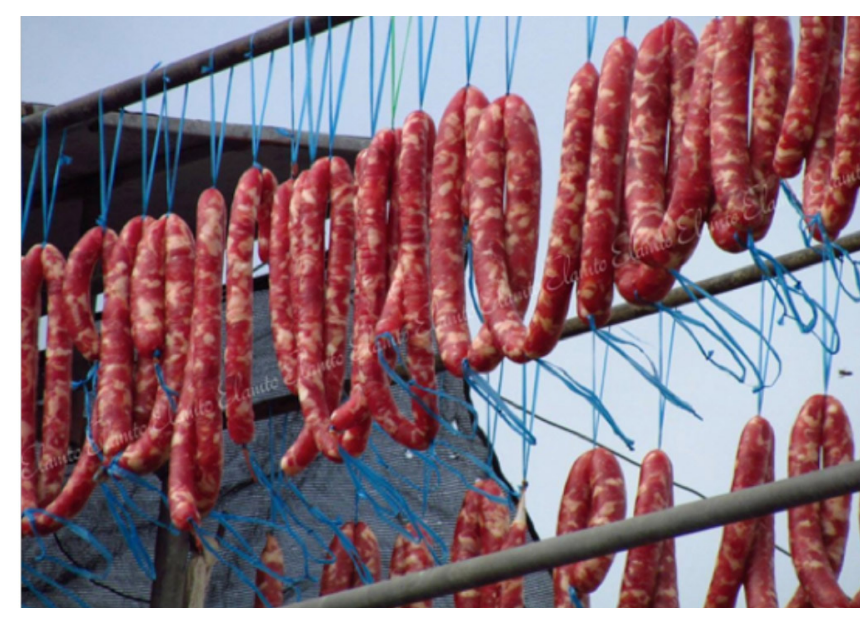

Figure 1: Air-drying of freshly-prepared Rodriguan chinese sausages.

\footnotetext{
1. Faculty of Agriculture, University of Mauritius, Reduit, Mauritius.

* Corresponding author

E-mail: k.boodhoo@uom.ac.mu
}

processing techniques were described. The Rodriguan chinese sausage, a traditional dry-cured pork-based product, is one of the most popular products and is considered as an authentic product of Rodrigues (Figure 1). It could be eventually promoted and marketed with an appellation such as the geographical indication label. However, from a food safety standpoint, there is a lack of information on the microbiological and physico-chemical characteristics of the finished product.

The main objective of this work was to determine the microbiological and physico-chemical characteristics of the Rodriguan chinese sausage with a view to establish the standard profile of the product. The study also aimed to identify weaknesses and make recommendations to improve safety, quality and shelf life of the product.

Sausages were sampled thrice from ten random family-owned processing units in seven villages and retail outlets of Rodrigues from November 2013 to January 2014. At each outlet, two sausages were taken and air-transported in sealed plastic bags within two days to the Faculty of Agriculture laboratory for analysis. All analyses were carried out using ISO (International Organization for Standardization) protocols.

The total viable count and lactic acid bacteria count ranged from 7.8 to 8.11 and from 7.08 to $7.50 \log _{10} \mathrm{CFUg}^{-1}$, respectively (Table I). The total coliform and Staphylococcus spp. counts were about $3 \log _{10} \mathrm{CFUg}^{-1}$ each. Neither Escherichia coli nor Salmonella spp. were detected in the samples analyzed. The

\section{Tableau I}

Microbiological characteristics of the Rodriguan chinese sausage $(n=30)$

\begin{tabular}{lc} 
Microbial flora & $\begin{array}{c}\text { Count }(\mathbf{l o g} \mathbf{C F U} / \mathbf{g}) \\
\mathbf{( 9 5 \%} \mathbf{C I})\end{array}$ \\
\hline Lactic acid bacteria & $7.08-7.50$ \\
Total viable count & $7.80-8.11$ \\
Total coliform & $2.87-3.31$ \\
Staphylococcus spp. & Only detected \\
& in some batches $(\sim 3)$
\end{tabular}

CI: confidence interval 
water activity, $\mathrm{pH}$ and lactic acid content of the sausages fell within the range of values typical of dry-fermented sausages (Table II). However, significant variations between samples

Table II

Physicochemical characteristics of the Rodriguan chinese sausage $(n=30)$

\begin{tabular}{lc} 
Parameter & $\mathbf{9 5} \% \mathbf{C l}$ \\
\hline $\mathrm{pH}$ & $4.60-4.82$ \\
Titratable acidity $(\%$ lactic acid) & $1.33-1.56$ \\
Water activity $\left(\mathrm{a}_{\mathrm{w}}\right)$ & $0.866-0.891$ \\
Moisture $(\mathrm{g} / 100 \mathrm{~g})$ & $53.82-57.44$ \\
Protein $(\%)$ & $31.0-36.0$ \\
Ash content $(\%)$ & $29.7-39.2$ \\
Fat $(\%$ dry basis) & $33.3-44.8$ \\
\hline & \\
Color & \\
Lightness $\left(\mathrm{L}^{*}\right)$ & $36.90-44.73$ \\
Redness $\left(\mathrm{a}^{*}\right)$ & $12.42-15.05$ \\
Yellowness $\left(\mathrm{b}^{*}\right)$ & $7.37-8.91$
\end{tabular}

CI: confidence interval were noted with regard moisture, protein, fat and ash contents. Similarly, water activity and $\mathrm{pH}$ values showed marked variations between the sausages. In contrast, no significant differences were noted in the $\mathrm{L}^{*}, \mathrm{a}^{*}$ and $\mathrm{b}^{*}$ color attributes as defined by the Commission internationale de l'éclairage (CIE).

Results confirmed that the Rodriguan chinese sausage satisfies the criteria of dry-cured raw meat products (3) and is overall a fairly safe and stable product. However, significant variations exist in its physico-chemical and microbiological characteristics probably due to variations in processing by the different artisans. There is thus a need to standardize the processing steps so as to improve the microbiological quality and safety of the sausage.

\section{REFERENCES}

1. BELMIN R., 2010. Analyse de la filière porcine de Rodrigues en appui à la labellisation des viandes et des produits de charcuterie. Saint-Pierre, Réunion, Cirad - réseau QualiREG. www.qualireg. org/FichiersComplementaires/RapportFinal_Belmin_filierePorcine_ Rodrigues2010.pdf (retrieved 21 Jan. 2011)

2. BOODHOO K., SANTCHURN S.J., LISETTE C., 2011. An appraisal of the small scale pork processing sector in Rodrigues. Part 1: Manufacturing practices and product quality. Univ. Mauritius Res. J. Sci. Technol. (Spec. Issue), $\mathbf{1 8 B}$.

3. LUCKE F.K., VOGELEY I., 2011. Traditional air-dried fermented sausages from Central Germany. Food Microbiol., 29: 242-246.

Accepted 30 April 2015; Online publication June 2015 